\title{
A Discussion of a Luxury Apparel Brand Strategy in an Emerging Market: Conceptual Model with Network Perspectives
}

\author{
Rachaya Kaolawanich $^{1}$, Hiroko Oe ${ }^{1}$, Yasuyuki Yamaoka ${ }^{2}$, Chih Yuan Chang ${ }^{1}$ \\ ${ }^{1}$ Bournemouth University, UK \\ ${ }^{2}$ The Open University of Japan \\ hoe@bournemouth.ac.uk
}

\section{Abstract}

This study explores the Burberry apparel brand's position and its strategic behaviour seeking new customers in the new market. This exploratory research pays particular attention to business potential and opportunities in an emerging market, Vietnam. To evaluate Burberry's strategies and the potential, the collaborative network relationships are discussed in details, that is followed by the discussion of the key themes for Burberry to consider in the Vietnamese market, where Burberry has recently begun expanding its businesses. The outcome of the study suggests that the Western luxury brand apparel needs to understand the targeted markets' systems and consumer behaviour, from there it is inevitable to design strategic plan how to engage the stakeholders in the ubiquitous supply chain relationships. In the end, a conceptual model with network perspectives is proposed: The model will be an analytical framework with key agenda items for the luxury brand which aims to enter the new market, and also the research limitations and further research opportunities are discussed.
Keywords

luxury brand, apparel; Vetnam

network perspective

\section{Introduction}

\subsection{Burberry as the Royal Brand from the UK}

Burberry is one of the UK's premier fashion apparel brands, founded in 1856 and currently taking steps towards becoming a global luxury fashion brand. It sells 'British' style and is well-known for its traditional, iconic trench coats, which are a symbol of the brand. Burberry has been awarded a Royal Warrant, and both celebrities and Burberry fans rely on the stylish design and quality of the garments (Mole, 2019).

In the mid-2000s, however, Burberry and other western luxury brands had become too reliant on sales to the new middle classes in China, where the possession of luxury goods is a status symbol. In line with the discussion of Asian consumer perceptions towards luxury brands, consumers' conspicuous attitudes are well-matched with the brand's values (Li et al., 2019) and the outstanding and well-known Burberry designer, Haymarket Check also acknowledges the potential of the Asian market for the brand (Sikarskie, 2019).

To support this luxury empire developed in the UK, Angela Ahrendts focused on its traditional assets and values (e.g., trench coats and tartan check) from 2006. She also opened the business on digitalised platforms, attempting to diversify the sales channels across boundaries. Following her push towards a new era for the empire, from 2014 her successor Christopher Bailey, one of the most influential fashion designers, also 
implemented innovative actions with a clearer business mission (Mendes, 2017; Lloyd \& Schaber, 2019). However, it was difficult for Bailey to sustain the business's performance in other countries, where Burberry's presence had started developing (Silva et al., 2019). The company's journey and challenges up to the year 2018 suggests the strategist's good lessons. In May 2014, Bailey took the role of chief creative and president of the company, with Riccardo Tisci succeeding his position in February 2018: Both of these legends have supported the historic British brand to sustain the business to attract new fans in the global market (Schweiger et al., 2020).

\subsection{Research Rationale}

There have been discussions relating the luxury brand and consumers' responses and behaviour. However, proposition of an analytical framework from a holistic view from a thematic-context has been waited especially in the difficult and uncertain global market, especially under the COVID-19 situation which has impacted on global enterprises as of when the authors are conducting this research note. Environmental issue such as the current COVID-19 situation has been hugely influencing the global supply chain network, that requires the social scientist to investigate further and discuss how to support supply chain management with actionable implications based on the collaborative commitments aiming to sustain the businesses. A discussion how to engage network actors to achieve the business goal under the uncertainty is one of the research topics in the contemporary context of businesses.

\subsection{Aim and Objectives}

This research aims to explore and evaluate a luxury brand's potential and strategies in the global market, using a British luxury brand Burberry's. Under the setting of an emerging market context with different consumer values and social system, potential collaborative strategies in the targeted market are to be summarised and proposed.

To achieve this aim, four objectives are emerged:

- Evaluate and discuss the potential of Burberry's business strategies and potential

- Examine the Vietnamese apparel market and consumer behaviour

- Discuss potential pathways to build robust strategies in acquiring new customers in Vietnam

- Propose an analytical framework for luxury apparel brand in the context of going in to an emerging market with different values and systems from the home nation.

\section{Review of Literature}

\subsection{Burberry's Strategy from a Network Perspective}

Burberry's overall business network can be separated into two types of strategic alliances. Firstly, vertical relations refer to both upstream and downstream vertical relations. Upstream vertical relations of Burberry are contracts with international suppliers. For example, C.F\&P, a manufacturer of leather goods in Italy, produced leather handbags for Burberry; thus C.F\&P is a first-tier supplier (Randelli and Lombardi, 2014). Additionally, there are several raw material suppliers who distribute leathers to C.F\&P, making them second-tier suppliers in Burberry's supply chain (C.F\&P, 2016). Secondly, regarding downstream vertical relations, Burberry sells products according to their distribution network, namely retail, wholesale, and licensing. The retail proportion is $82 \%$ of sales, and $70 \%$ of retail sales are influenced by digital marketing (Burberry, 2018). 
Consequently, another significant area for consideration could be the strategies that Burberry utilises to enhance B2B and B2C channels in Vietnam.

Burberry has many competitors, including international brands such as Coach, Gucci, Prada, and Louis Vuitton (mbaskool.com 2019). Moreover, there are several UK brands that are also competitors of Burberry, such as Alexander McQueen, Stella McCartney, and Vivienne Westwood (Bhasin, 2018). It has been demonstrated that there is intensive competition in the apparel industry, thus Burberry should focus on maintaining its brand identity, trademark, and unique digital marketing platform to achieve a sustainable competitive advantage (IvyPanda, 2019). This advantage could provide Burberry with the opportunity to expand into a new market. Burberry's operating collaboration with Farfetch, the leaders in global technology platforms, enables Burberry to expand its customer base to reach customers in over 150 countries around the world and develop a deeper relationship with other e-commerce partners (Burberry, 2018; Silvano, 2020). Accordingly, this complementary partner combined with Burberry's digital marketing capabilities could be their main strategy for expanding their brand name, trademark, and reputation on the worldwide stage. Figure 1 demonstrates a map of the collaborative relations of Burberry's business perspective.

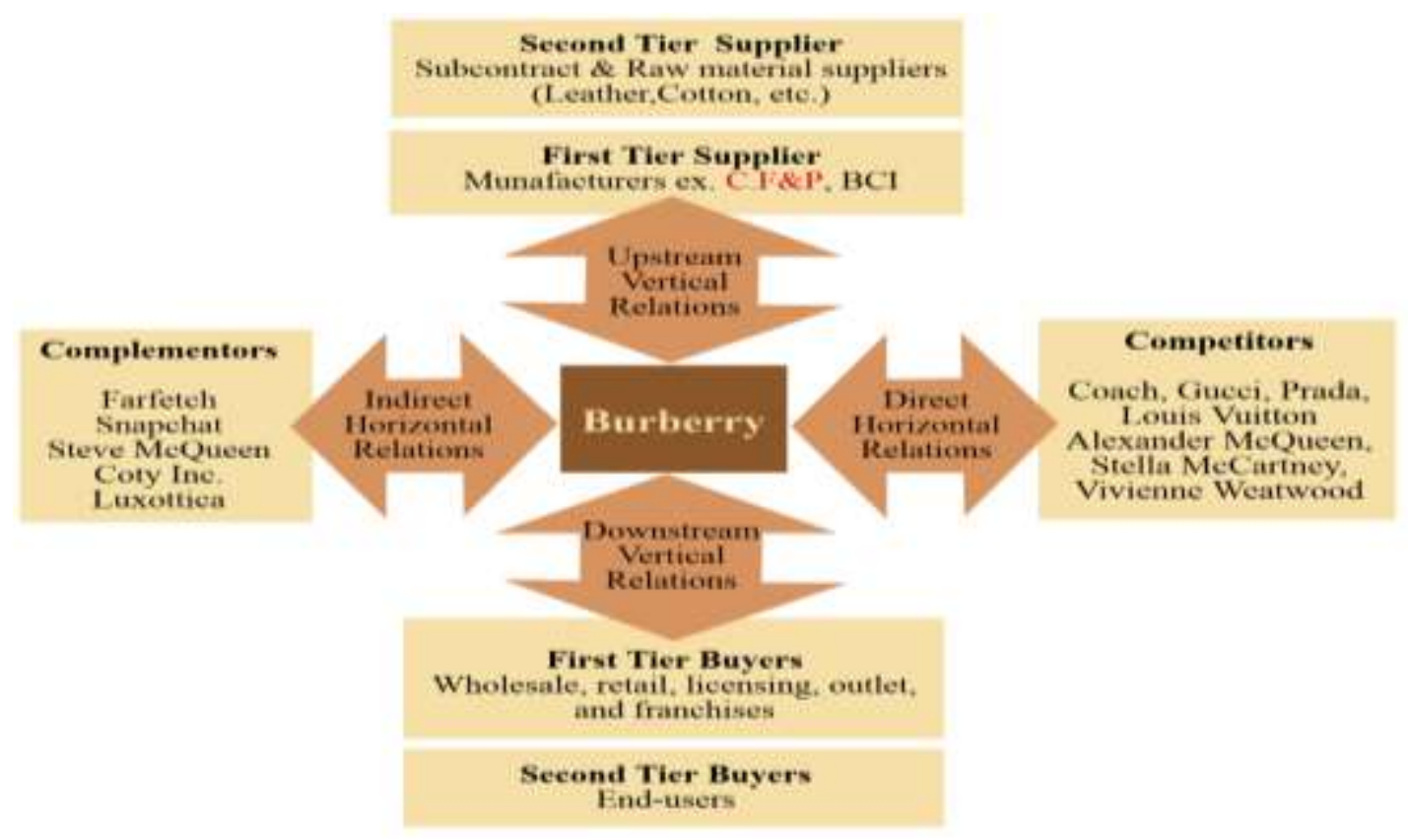

Figure 1. An image of Burberry's relational actors and collaborations (Adapted from De Wit \& Mayer, 2010)

\subsection{Burberry's B2B Collaboration Perspective}

Transparency in Burberry's supply chain reveals that the existing network enhances the product and network relations of business operations (Kingdom, 2015). Burberry does not only pay attention to the quality of raw materials, but also focuses on sustainability. For example, Burberry weaves and stitches fabric in their factories using cotton sourced from the Better Cotton Initiative (first-tier supplier) who are in contact with a million cotton farmers (second-tier suppliers) around the world, to reduce environmental issues and create a sustainable supply of raw material (Burberry, 2019). Moreover, Burberry has expanded their business using a backward integration strategy by acquiring part of C.F\&P (first-tier supplier), their leather goods supplier. The relational collaboration with relevant 
stakeholders enables Burberry to acquire new customers of both B2B and B2C networks to develop strategic business body to penetrate into the new market (Iglesias and Schults, 2020). This acquisition will allow Burberry to reduce production costs and delivery expenditure. Also, it will enable Burberry to control the quality of material and the leather goods' sustainability.

\subsection{Burberry's Marketing Communication Strategies}

Burberry has become the first brand to use social media, specifically Snapchat, to grant customers access to special content at Burberry stores. Burberry collaborates with Steve McQueen (the Oscar-winning director) to produce the exclusive content in Snapchat. The strategy has added value to the Burberry brand and provided a new experience for the customer. Also, it has enabled Burberry to expand the brand to a new, younger market by targeting existing Snapchat users, and could also provide a potential channel for Burberry to deepen its relationship with customers (edublogs, 2016). Hence, digital marketing collaboration could increase Burberry's opportunities to reach the Vietnamese apparel market. In addition, Burberry has applied a diversification strategy in collaborating with other businesses such as Coty Inc., a global leader in beauty products (NYSE, 2019).

These collaborations lead Burberry's expanding market share, enhancing the brand value, and ensuring in attracting new customers in Vietnamese market (Graesser, 2019; Liu et al., 2019; Dinh et al., 2019).

\subsection{Analytical Framework}

Figure 2 shows an analytical framework based on the discussions so far, which indicates a conceptual pathway how British luxury brand enters into the new market to sustain and expand the businesses based on the brand value and strategic assets which have been established in the global market. Based on the framework, this research will entail the targeted market analysis and potential for Burberry to penetrate.

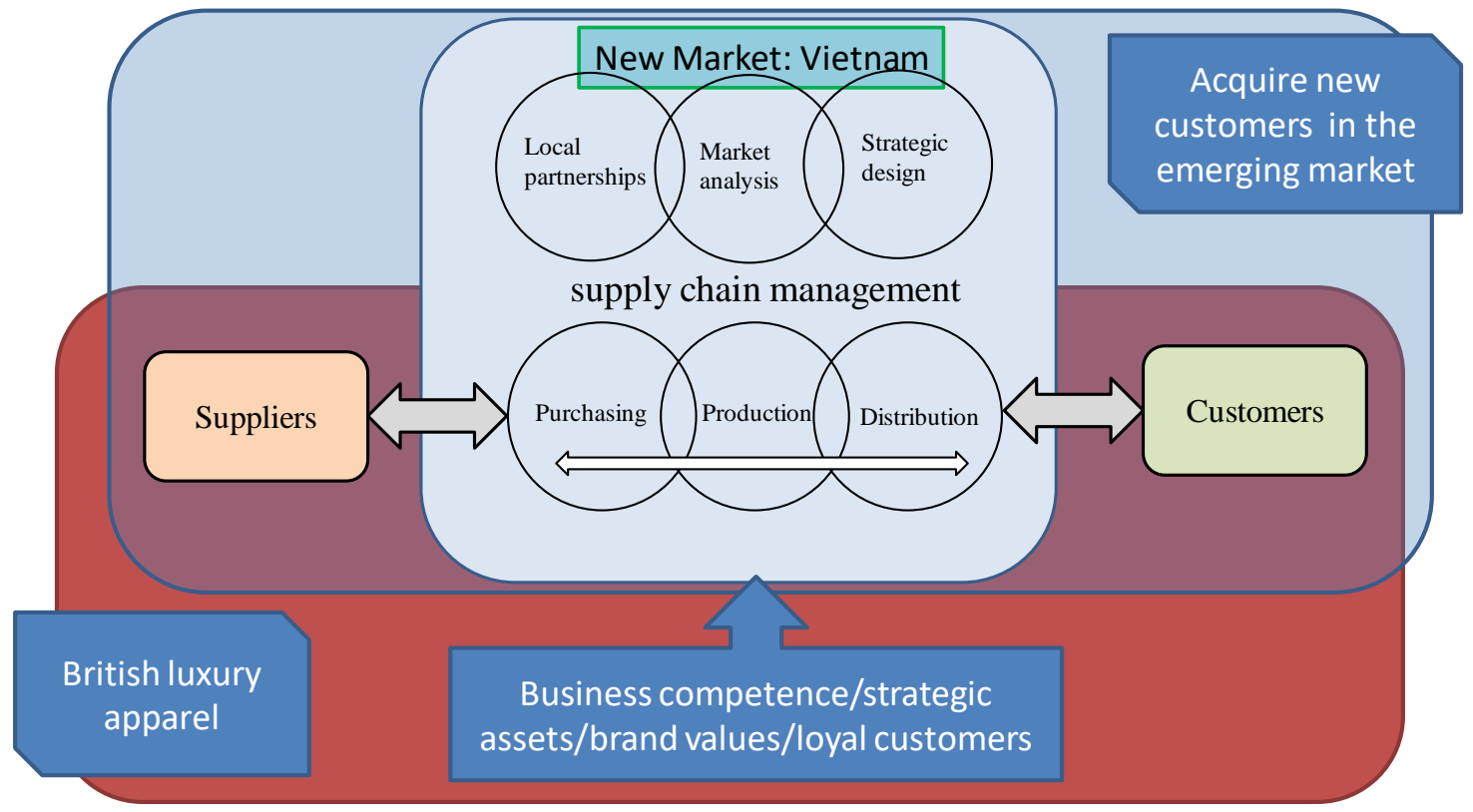

Figure 2. Network perspectives of business (authors' collections) 


\section{Research Methods}

\subsection{Approach}

A term-based search method was applied to this research which analysed the literature of peer-reviewed articles in English-language journals and relevant professional articles available from online databases (Groß, 2014). Based on the desk research, a literature review of the articles in the theme of this study was carried out to develop actionable implications for Burberry's business strategies in the new market. From this process, actionable recommendations for the British luxury apparel brand for expand the business network and sales channels in Vietnamese market based on the own competences and consumer behaviour (Baumeister, 2013; Webster and Watson, 2002).

\subsection{Data Sources and Study Selections}

The published articles were identified through searches in EBSCO and ScienceDirect databases during the period from 2000 to 2020. Keywords, titles and abstract information were checked and selected (Levy and Ellis, 2006). The main search terms were categorised in two groups: (a) "Burberry," "business strategy," and "Vietnam," and (b) "apparel," "Vietnam," "consumer," and "market." The symbol \# was used for identifying all possible words with these two key terms: for instance, "strateg\#" was used to search, e.g. strategy, strategies, strategic, strategize, and strategise. The professional materials such as books, company reports, news articles on newspapers, and other relevant Asian online materials from non-academic resources were also searched.

Only English articles were considered. Book chapters and studies that have been published in non-peer-reviewed journals were also considered because the main aim of this research note is to make an exploratory discussion as a pilot study before conducting a precise systematic review. A manual selection of the title information of the identified resources for this research revealed 317 article which were to be further reviewed as the basis for developing research outcome with actionable implications. In doing so, the authors attempted to focus more on the recent publications so that the critical discussions can be conducted based on the recent topics and strategies of Burberry's.

\section{Discussion}

\subsection{Aspects of the Vietnamese Apparel Market and Industry a. Vietnam's Position in the Global Apparel Market and Industry}

In Vietnam, international brands account for $60 \%$ of the total retail market. Nowadays, Vietnamese are more able to access luxury brand retail outlets such as Dior and Louis Vuitton, due to both brands being available on commercial streets and the huge populations in Dong Khoi and Nguyen Hue in Ho Chi Minh City. In addition, Vietnamese retailers have started offering international brands to Vietnamese customers in stores called 'multi-brand outlets' (Vietcetera, 2019).

\section{b. Supply and Distribution Network of the Vietnamese Apparel Market}

With regard to suppliers of Vietnam's garment industry, the United States is a huge supplier of cotton, providing 53\% of Vietnam's total cotton supply (USDA Foreign Agriculture Service, 2018). Although Vietnam needs to import raw materials, Vietnam's government also supports the apparel industry by providing reductions to import duties and tariff rates on raw material production. As part of the distribution network, department stores play a key role in retail sales since the economic reform, and retail sectors have been 
restructured with new emerged store formats such as supermarkets, mini marts, and convenience stores: Also, online retail sales in Vietnam have significantly increased, by around $61 \%$ in the last year; however, they still only account for $2.8 \%$ of total retail sales (Vietcetera, 2019). It is possible that Burberry could focus on collaborating with local department stores to reach Vietnamese customers, while continuing to utilise Burberry's digital knowledge and leveraging of complementors such as eMarketing.

\section{c. Collaborative Relationships}

Abdullah et al. (2005) pinpointed collaboration as a valuable asset for organisations such that, with collaboration, organizations can better achieve their desired ends together rather than achieving it alone. Organisations that embrace collaboration can create a valuable advantage of attaining their objectives (Abdullah et al., 2005). Burberry has a brand presence for more than 163 years giving them an outstanding knowledge of the retail market as well as having achieved multiple successful collaborations with strategic alliances (Burberry 2019). Burberry's creative collaborations have successfully combined the relational actors' skills to attain set goal, even with the collaboration between rival firms who operate within the same sector which enabled the win-win relationships within the luxury apparel brands (Parida et al., 2013)

Burberry considers having close monitoring and control over the supply chain processes and maintaining their reputation as an important value for the company (Moore and Birtwistle 2004). Therefore, while considering the collaborations in Vietnam the prospective partners should have the characteristics to perform up to 4Cs (e.g., capability, compatibility, commitment and control) (Mellahi and Frynas 2015). Conflicts in collaboration can also arise from differences in perspective of the parties and lack of communication might be potential challenges for the sustainable relationships with commitments and trust throughout the collaboration (Vaaland 2004; Shen and Mikschovsky, 2019). Burberry must take measures to ensure cultural and language constraints become an obstacle. Moreover, to ensure a sustainable behaviour in the Vietnamese market, Burberry should abide to the ethical code of conduct and legal policies set in Vietnam when making collaborations (Le et al., 2019).

Vietnam's recently signed with Comprehensive and Progressive Agreement for Trans-Pacific Partnership (CPTPP), members of CPTPP countries have agreed to eliminate duties from 97 to $100 \%$ of tariffs for imports from Vietnam that qualify under the applicable rules of origin (Burke al et., 2019) as well as Vietnam's signing or the EUVietnam-Free Trade Agreement (FTA) which aims to protect investors and investments has made Vietnam open to international trade and investment (Sardinha, 2017). Thus, Burberry's products manufactured can be imported to Vietnam with low tariffs decreasing cost on the company's entry into the new market.

Vietnam developed industrial zones mainly for production exports and high tech in order to attract more foreign investors, as of December 2018, 326 zones were created with 249 already operating (Huong \& Dung, 2019; Khuong \& Yen, 2016). Burberry could utilize their manufacturing within these industrial zones and benefit from the low labour cost. Not only the public sectors' interventions, Non-Governmental Organization (NGO's) and United Nations are also critical collaborators for the business. Burberry has a good reputation of collaborating with multiple NGO's. According to the Voluntary National Review (2018), United Nations Sustainable Development Goals (SDGs) have been aligned with Vietnam's long-term development strategy, Vietnam's business council for sustainable development has been an initiative by the public sectors to encourage foreign and local investment and do business in lined with SDGs. Vietnam joined International 
Labor Organization (ILO) in 1992, and they are aiming to promote ethical employment, build healthy labour market to support Vietnamese labour force, (International Labor Organization 2019). Burberry has also committed to human rights policy (Burberry 2019b), collaboration with ILO in Vietnam has been enhancing Burberry's reputation in Vietnam as a sustainable company. Burberry could collaborate with Better Work Vietnam which is partnership with ILO and International Finance Corporation and World Bank Group to improve working conditions as well as increase competitiveness of the garment industry (Brown et al., 2014) collaborating with Better work Vietnam can help provide work opportunities.

\subsection{Consumer Behaviour in the Vietnamese Apparel Market \\ a. Consumers Behaviour}

Vietnamese consumers are more likely to have a high demand for fashionable products, and are willing to pay a higher price to develop their standard of living (Liu and Zhang, 2019). Vietnamese consumers have got to purchase luxury goods with (HKTDC, 2017), and this has led Vietnam to become a potential market for luxury apparel brands such as Burberry. Also, in this digital age, Vietnamese consumers tend to purchase products online (Le and Hoang, 2020) and the variety of available products online attracts more consumers (Giao et al., 2020). Consequently, Burberry should develop an online shopping platform with more languages and features to satisfy customers, as well as considering it a strategy to enter Vietnam.

Cultural issues affecting B2B collaboration and communications in Vietnam should be also carefully examined. Figure 3 shows a cultural comparison between the United Kingdom and Vietnam, with Hofstede's six dimensions. There are two crucial different dimensions: The power distance score and individualism. This could demonstrate that group opinion is significant to Vietnamese decision-making, while British people decide individually (Ngo et al., 2019). Burberry should be aware of communication etiquette and consider these differences while accessing the stakeholders and building robust partnerships. A UK based company also must consider the hierarchical order and the way of managing its human resource while entering Vietnam market. In terms of B2B collaboration, it takes time for company to build mutual trust and also need to show respect and genuine interest while communicating with partners because Vietnamese place a great deal of saving face (Rowley et al., 2007). As noted, cultural differences including linguistic barriers should also be considered carefully in the business context (Syakur et al., 2020).

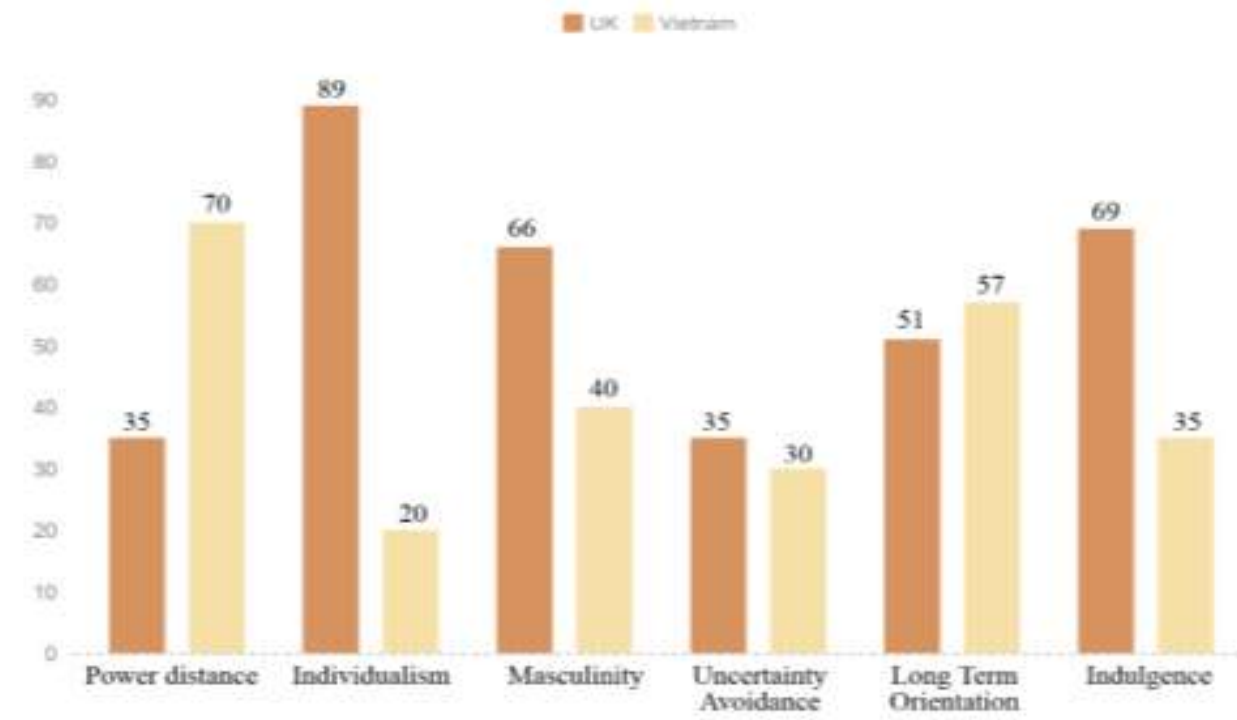

Figure 3. Culture comparison: The United Kingdom and Vietnam (Hofstede Insight, 2019) 


\section{b. Consumer Behaviour and Attitudes in the Vietnamese Apparel Market}

Consumer behaviour and attitudes are important factors that need to be understood while making participation strategy. Vietnamese consumers' attitudes, values and behaviours have changed rapidly (Tambyah et al. 2009). The conflicts between 'traditional self' and 'modern self' have influenced the past values of Vietnamese consumers (Lee \& Nguyen, 2017; Nguyen et al. 2009). Furthermore, in Vietnam, there are competitions among foreign brands such as from Japan, South Korea, Europe and the U.S., thus, understanding of Vietnamese consumers' behaviours toward foreign brands is also necessary for firms to be prepared for the competition in Vietnam market (Vuong \& Khanh, 2020).

Vietnamese consumer's confidence level has peaked in the past decade (Nielsen 2018) and the Vietnamese customers are willing to expend their expenditures on apparel products. Also, the young generation spend more on apparel product than average because of high individualism which makes them want to be stylish (Nguyen et al., 2019). The country's large young population also generates the potential for luxury market (Earl, 2012; Le and Quy, 2020). Nayak et al. (2020) discussed Vietnamese aged between 18 and 35 years old are now trying new things and experiences, and younger consumers think luxury is about new experiences (Vuong et al., 2019). In line with these discussions, Kusumadewi (2019) suggested that the influence of cultural and social values on consumers' individual behavior should be considered carefully in the international market context. Current snapshots of Vietnamese consumers' behaviour is summarised in Table 1 based on the discussions developed by Ferrell and Hartline (2011).

Table 1. Vietnamese consumer behaviors (amended from Ferrell and Hartline 2011)

\begin{tabular}{|c|c|}
\hline Stage: & Vietnamese consumer behaviors. \\
\hline Neod Recognition & $\begin{array}{l}\text { - Northern (Hanol): Do not want to lose "face" } \\
\text { - Southern (HCM): I buy it because I want it }\end{array}$ \\
\hline foformation Search & $\begin{array}{l}\text { - Increase in mobile and internet search. The effectiveness rate of digital ad on } \\
\text { mobile phone is } 75 \% \text { (Nielson, } 2017 \text { ) } \\
\text { - Vietnam is ranked } 7 \text { th in using social media over the world } \Rightarrow>\text { a fot of influence } \\
\text { from social media (We are sodial, 2018) } \\
\text { - High collectivism }=>\text { reference groups are verv important (Hofstede insight, 2019) }\end{array}$ \\
\hline Evaluation of Afromativos & $\begin{array}{l}\text { - Urban: Passionate about luxury brands } \\
\text { - Rural: Rely on recommendations from retailers } \& \text { commercials (Sweden Business in } \\
\text { Vietnam, 7018) } \\
\text { - In urban area, most important factors when buying clothes are cost, design and } \\
\text { quality respectively (osme-Survers, } 2017 \text { ) }\end{array}$ \\
\hline Purchase Decisions & $\begin{array}{l}\text { - Majority of grocery purchase is still made in stores (Swedon Business in Vietnam, 2018) } \\
\text { - Prefer to pay by cash (Kantar worddsaned, } 2017 \text { ) } \\
\text { - E-commerce is growing. 98\%lnternet users have bought something online } \\
\text { (Nintsan, 2018) }\end{array}$ \\
\hline Post Purchase hethaviors & It totally depends on individual experience. \\
\hline
\end{tabular}

The Vietnamese consumers who value more on latest fashion, well-known brand and country of origin preferred foreign fashion brands over local fashion brands (Lee and Nguyen 2017). They considered that foreign brands as higher quality and more attractive than local fashion brands.

\section{c. topics of Vietnamese Young Consumers: Ethical Values}

Vietnam government adopts many policies to protect intellectual properties such as copyrights and trademarks for company to sell and distribute luxury goods in Vietnam (Fforde, 2019). However, Vietnam still has one of the highest rates of intellectual property 
violations in the world, especially for branded goods which are widely re-produced in this country (Long \& Vinh, 2017). Thus, the risks brought by counterfeits are still existing while selling luxury products in Vietnam.

Vietnam's Ecommerce Association estimated annual growth rates to reach 16.5\% from 2017 to 2021 (Vietcetera 2017). The expansion of the youth based middle class in Vietnam is has been characterized as internet fueled class, the increase use of social platforms such as Facebook and Instagram and as smartphones becoming accessible and affordable the online user penetration especially in online shopping has risen (Dabija et al., 2019; Vietcetera 2017)

Young consumers' perceptions for luxury value can be also discussed with a theme of ethical views (Chen et al., 2019; Gazzola et al., 2020; Le \& Quy, 2020). They have a great desire to save their money and invest in projects that serve society and the environment. This generation's personality traits such as ecological consciousness and social consciousness greatly affect their purchasing decisions. They always seek diversity and variety to spread the values of equality and justice in society (Chen et al., 2019). In doing so, Vietnamese younger consumers are prone to use online shopping channels (Do et al., 2019; Ho \& Chen, 2014; Van Nguyen et al., 2019).

There is another B2B topic we should consider: Duc \& Nananukul (2018) suggested that supply chain model itself should be redesigned from renewable energy resource-based, such as biomass energy should have impact on rearranging the whole supply chain relationships. In line with the boosting CSR requirements with UN SDGs impact on the businesses, Gopi \& Rao (2016) discussed the manufacturing and delivering the products and services have to contribute in reforming the global business to a new economic paradigm.

\section{Conclusion}

\subsection{Overall Discussion with Contribution}

In recent years, the Asia-Pacific area has become the most important region for Burberry, not only because it provides the largest market share of its revenues (41\%), but also because it has been the fastest growing market, which has enabled Burberry to sustain its business as a whole (Burberry, 2018).

The research analysed Burberry's' network strategies of collaborations with relevant stakeholders. Ho et al. (2017) suggested the supply chain collaboration should be the key for the businesses to enhance the sustainability especially in the textile and apparel industry. According to economic growth and the demand for internationally branded products, the Vietnamese market is an appealing market for Burberry to enhance its business in the coming years. This is also a great opportunity for Burberry to consider its new market participation for Burberry to seek the business opportunities in Vietnam. At the same time, business background infrastructures such as intellectual property rights should be paid attention to (Department of International Trade, 2016). How to fight against the counterfeit issues have been critical for Western luxury brands in the global markets.

Figure 4 demonstrates the key agenda for the luxury apparel brands when they plan to enter into the new market. 


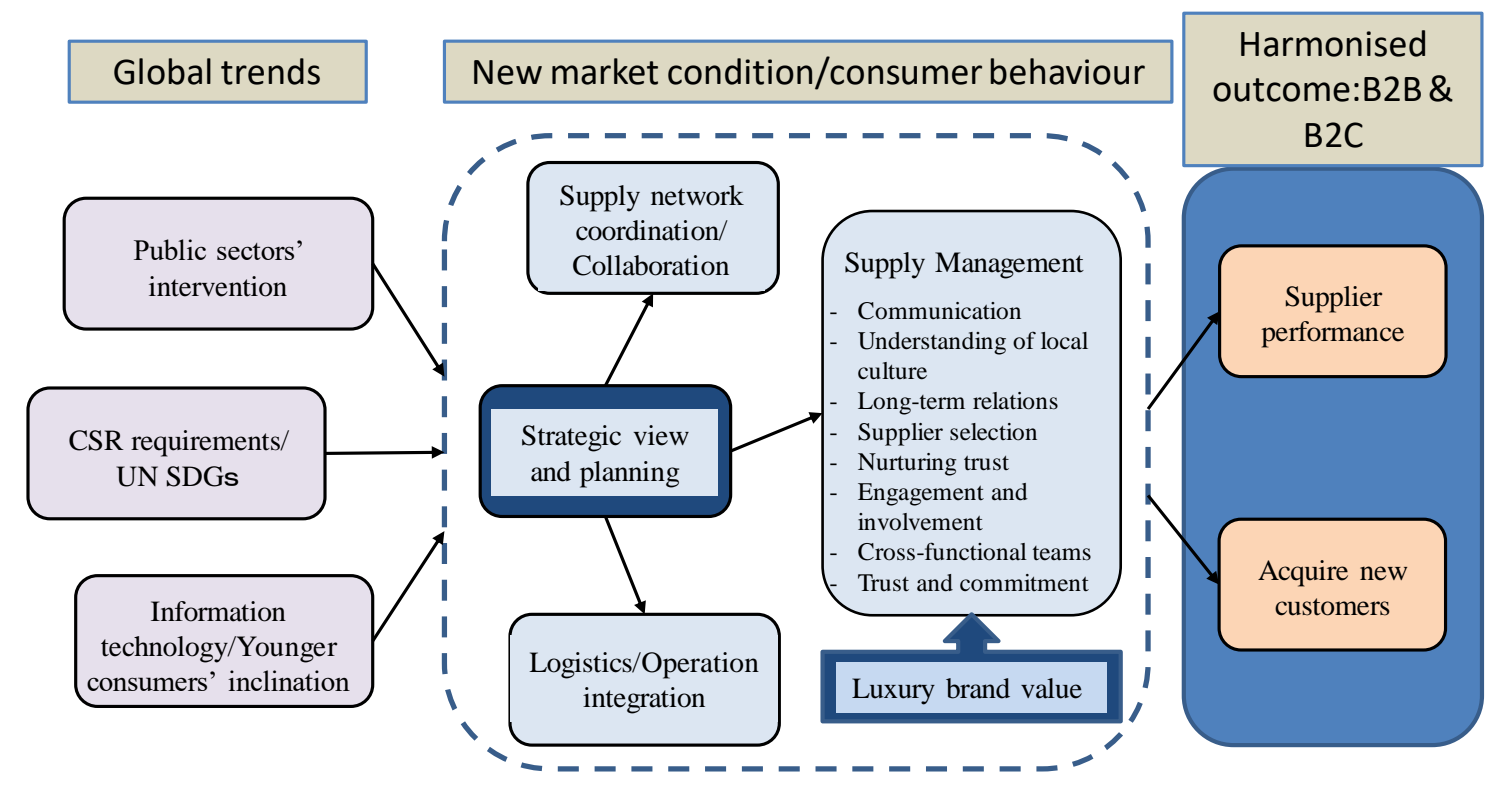

Figure 4. Key agenda for the luxury apparel brands when entering into the new market (Adapted from Chen \& Paulraj, 2004)

\subsection{Limitations and Future Research Opportunities}

As an exploratory research, this study stays as a pilot stage and the outcome should be validated to enhance the contribution by providing more actionable recommendations based on the apparel brands for the next phase.

From the globalised business perspectives, the relevant network actors should share the values and an instrument is needed to engage the stakeholders in the ubiquitous relationships. Especially under the huge COVID-19 impact on the global supply chain network, how to sustain the global businesses as network actors should remain one of the key agenda items for the future. How to tackle the obstacles for the seamless network relationships would be another key research opportunity for the business researchers, as well.

\section{References}

Abdullah, R., Sahibudin, S., Alias, R. A., \& Selamat, M. H. (2005). Collaborative knowledge management systems for learning organisations. Journal of Information \& Knowledge Management, 4(04), 237-245.

Anh, N. (2017). Fast fashion competition bursting at the seams in Vietnam - VnExpress International. VnExpress International - Latest news, business, travel and analysis from Vietnam. Available from: https://e.vnexpress.net/news/business/fast-fashioncompetition-bursting-at-the-seams-in-vietnam-3659659.html [Accessed 10 April 2020]

Baumeister, R.F. (2013). Writing a literature review, in Prinstein, M.J. and Patterson, M.D. (Eds), The Portable Mentor: Expert Guide to a Successful Career in Psychology, 2nd ed., Springer Science, New York, NY, pp. 119-132.

Bhasin, H. (2018). Top British Fashion brands in 2018 - Popular British Fashion brands. Available from: https://www.marketing91.com/top-british-fashion-brands-in- 
2018/?fbclid=IwAR3R3JdGFD0_e0GNB63RgDf1DnZ5L45dxPore3RH9EAmHEC

X3BmiuW5LpNY [Accessed 9 March 2020]

Brown, D., Dehejia, R., \& Robertson, R. (2014). Regulations, monitoring and working conditions: Evidence from better factories Cambodia and better work Vietnam. In Creative Labour Regulation (pp. 185-203). Palgrave Macmillan, London.

Burberry (2018). Burberry Annual Report 2017-2018. Available from: https://www.burberryplc.com/content/dam/burberry/corporate/Investors/Results_Rep orts/2018/Burberry_AnnualReport_FY17-18.pdf [Accessed 8 April 2020]

Burberry (2019a). Product. Available from: https://www.burberryplc.com/en/responsibility/responsibilitystrategy/product.html?fbclid=IwAR0ilrNiARsxr57rXPK5Mu_OMJdqrbLas9dkDChQQk2EEHtcUqPOYwT4AU [Accessed 9 March 2020]

Burberry (2019b). Working at Burberry. Available from: https://www.burberryplc.com/en/people/working-at-burberry.html [Accessed 8 April 2020]

Burke, F., Nguyen, T. and Tran, N. (2019). CPTPP - Customs issues for Vietnam. [online] Global Compliance News. Available from: https://globalcompliancenews.com/cptppcustoms-issues-vietnam-20190128/ [Accessed 9 May 2020].

C.F\&P (2016). CF\&P | RAW MATERIALS. Available from: http://www.cfepsrl.com/en/materie-prime/ [Accessed 8 March 2020]

Chen, I. J., \& Paulraj, A. (2004). Understanding supply chain management: critical research and a theoretical framework. International Journal of production research, 42(1), 131-163.

Chen, M. H., Chen, B. H., \& Chi, C. G. Q. (2019). Socially responsible investment by generation Z: a cross-cultural study of Taiwanese and American investors. Journal of Hospitality Marketing \& Management, 28(3), 334-350.

Dabija, D. C., Bejan, B. M., \& Dinu, V. (2019). How Sustainability Oriented is Generation $\mathrm{Z}$ in Retail? A Literature Review. Transformations in Business \& Economics, 18(2).

Department of International Trade (2016). Doing business in Vietnam: Vietnam trade and export guide. Available from: https://www.gov.uk/government/publications/exporting-to-vietnam/exporting-tovietnam\#contents [Accessed 6 March 2020]

Dinh, H. P., Nguyen, P. V., \& Hosseini, J. C. (2019). The impact of product diversification and capital structure on firm performance: evidence from Vietnamese manufacturing enterprises. Journal for Global Business Advancement, 12(1), 95-116.

Do, T., Nguyen, T., \& Nguyen, C. (2019). Online Shopping in an Emerging Market. Journal of Economics and Management Sciences, 2(2), 1.

Duc, D. N., \& Nananukul, N. (2018, April). Supply chain model for renewable energy resource from biomass in Vietnam. In 2018 5th International Conference on Industrial Engineering and Applications (ICIEA) (pp. 520-525). IEEE.

Earl, C. (2012). Vietnamese middle-class household. Pacific Geographies, 17.

edublogs (2016). Why Burberry's sponsored Snapchat Discover channel is marketing brilliance | My Exploration of Digital Marketing [online]. Blogs.brighton.ac.uk. Available from: http://blogs.brighton.ac.uk/yssdigital/2016/04/15/why-burberryssponsored-snapchat-discover-channel-is-marketing-brilliance/ [Accessed 9 March 2020]

Ferrell, O. C., \& Hartline, M. D. (2011). Marketing management strategies. South-Western Cengage Learning.

Fforde, A. (2019). From plan to market: The economic transition in Vietnam. Routledge. 
Gazzola, P., Pavione, E., Pezzetti, R., \& Grechi, D. (2020). Trends in the Fashion Industry. The Perception of Sustainability and Circular Economy: A Gender/Generation Quantitative Approach. Sustainability, 12(7), 2809.

Giao, H., Vuong, B., \& Quan, T. (2020). The influence of website quality on consumer's eloyalty through the mediating role of e-trust and e-satisfaction: An evidence from online shopping in Vietnam. Uncertain Supply Chain Management, 8(2), 351-370.

Gopi, A. G., \& Rao, B. (2016, September). Products and services in new economic forms. In 2016 Portland International Conference on Management of Engineering and Technology (PICMET) (pp. 1043-1050). IEEE.

Graesser, A. (2019). Digital Strategies. In Run IT (pp. 165-211). Springer, Cham.

Groß, M. (2014). Mobile shopping: a classification framework and literature review, International Journal of Retail \& Distribution Management, 43(3), 221-241.

HKTDC (2017). Vietnam's Consumer Preference for “Affordable Luxuries” | Hong Kong Means Business. Hong Kong Means Business. Available from: https://hkmb.hktdc.com/en/1X0A9WQM/hktdc-research/Vietnam\%E2\%80\%99s-

Consumer-Preference-for-\%E2\%80\%9CAffordable-Luxuries\%E2\%80\%9D [Accessed 12 March 2020]

Ho, D., Kumar, A., \& Shiwakoti, N. (2017, December). Supply chain collaboration-A case study of textile and apparel industry. In 2017 IEEE International Conference on Industrial Engineering and Engineering Management (IEEM) (pp. 1367-1371). IEEE.

Ho, T. H. L., \& Chen, Y. (2014). Vietnamese Consumers' Intention to Use Online Shopping: The Role of Trust. International Journal of Business and Management, $9(5), 145$.

Hofstede's insights (2019) Compare Countries, Available from: https://www.hofstedeinsights.com/ [Accessed 28 April 2020]

Huong, H. T. H., \& Dung, N. T. T. (2019). Factors Affecting Investors' Satisfaction in Industrial Zones and Results in Investment Attraction in Industrial Zones in Binh Dinh Province, Vietnam. Economic Research, 3(4), 33-45.

Iglesias, O., Ind, N., \& Schultz, M. (2020). History matters: The role of history in corporate brand strategy. Business Horizons, 63(1), 51-60

International Labor Organization (2019). ILO in Viet Nam. Available from: http://www.ilo.org/hanoi/lang--en/index.htm [Accessed 9 March 2020].

IvyPanda (2019). Business Strategy Report: Burberry Plc. Available from: https://ivypanda.com/essays/business-strategy-report-burberry-plc/ [Accessed 9 March 2020]

Khuong, M. N., \& Yen, V. H. (2016). Investigate the Effects of Job Stress on Employee Job Performance--A Case Study at Dong Xuyen Industrial Zone, Vietnam. International Journal of Trade, Economics and Finance, 7(2), 31.

Kingdom, B. (2015). Burberry-Home. Available from: https://uk.burberry.com/legalcookies/transparency-in-the-supply-chainmodern-slavery-statements/ [Accessed 9 March 2020]

Kusumadewi, R. (2019). The Role of Marketing and Individual Environment Association in Elevating the Customer Value. Budapest International Research and Critics Institute (BIRCI-Journal): Humanities and Social Sciences, 2(4), 451-460.

Laasch, O. (2019). An actor-network perspective on business models: How 'Being Responsible'led to incremental but pervasive change. Long Range Planning, 52(3), 406-426. 
Le, N. B. M., \& Hoang, T. P. T. (2020). Online Buying Behaviors on E-Retailer Websites in Vietnam: The Differences in the Initial Purchase and Repurchase. In Intelligent Computing in Engineering (pp. 845-851). Springer, Singapore.

Le, N. T. C., \& Quy, V. T. (2020). Personal Values of Luxury Services Consumption: A Confucian Culture Perspective. Journal of International Consumer Marketing, 1-13.

Lee, T. R., \& Le, T. P. N. (2010, October). Powerful supply chain: Apply areas of social and science management to supply chain management to enhance the coordination of supply chain participants. In 2010 8th International Conference on Supply Chain Management and Information (pp. 1-6). IEEE.

Lee, J., \& Nguyen, M. J. (2017). Product attributes and preference for foreign brands among Vietnamese consumers. Journal of Retailing and Consumer Services, 35, 7683.

Le, Q. A., Tran, V. A., Duc, N., \& Long, B. (2019). The Belt and Road Initiative and Its Perceived Impacts on the Textile and Garment Industry of Vietnam. Journal of Open Innovation: Technology, Market, and Complexity, 5(3), 59-62.

Levy, Y. and Ellis, T.J. (2006). A systems approach to conduct an effective literature review in support of information systems research, Informing Science Journal, 9, 181-212.

Li, J., Guo, S., Zhang, J. Z., \& Sun, L. (2019). When others show off my brand: self-brand association and conspicuous consumption. Asia Pacific Journal of Marketing and Logistics.

Liu, S., Perry, P., \& Gadzinski, G. (2019). The implications of digital marketing on WeChat for luxury fashion brands in China. Journal of Brand Management, 26(4), 395-409.

Liu, Y., \& Zhang, T. (2019, June). Research on Digital Marketing Strategies of Fast Fashion Clothing Brands Based on Big Data. In 2019 34rd Youth Academic Annual Conference of Chinese Association of Automation (YAC) (pp. 552-556). IEEE.

Lloyd, C., \& Schaber, F. (2019, July). Britishness: Heritage, Tradition and Authenticity. In International Conference on Fashion communication: between tradition and future digital developments (pp. 89-100). Springer, Cham.

Long, H. C., \& Vinh, N. N. (2017). Factors Influencing Consumers' Attitudes towards Counterfeit Luxury Fashion Brands: Evidence from Vietnam. Global Journal of Management and Marketing Volume, 1(2), 63-76.

Mellahi, K. and Frynas, J. (2015). Global strategic management. 3rd ed. Oxford: Oxford University Press.

Mendes, S. (2017). See Now, Buy Now: The position of the press in fashion's' new'consumer model. International Journal of Fashion Studies, 4(2), 285-292.

Mole, S. (2019). Fashion and Street-Style Blogs: The New Hierarchies Arising within the British Fashion System. In Fashion and Contemporaneity (pp. 132-150). Brill Rodopi.

Moore, C. and Birtwistle, G. (2004). The Burberry business model: creating an international luxury fashion brand. International Journal of Retail \& Distribution Management, 32(8), 412-422.

Nayak, R., Panwar, T., \& Nguyen, L. V. T. (2020). Sustainability in fashion and textiles: A survey from developing country. In Sustainable Technologies for Fashion and Textiles (pp. 3-30). Woodhead Publishing.

Ngo, T., Tran, T., Tran, M., Nguyen, Q., \& Hoang, V. (2019). A study on relationship between cultural industry and economic growth in Vietnam. Management Science Letters, 9(6), 787-794. 
Nguyen, M. T. T., Nguyen, L. H., \& Nguyen, H. V. (2019). Materialistic values and green apparel purchase intention among young Vietnamese consumers. Young Consumers.

Nguyen, A. S., \& Le, M. T. (2019, July). A Risk Management Tool for the Reverse Supply Chain Network. In 2019 International Conference on System Science and Engineering (ICSSE) (pp. 391-396). IEEE.

NYSE (2019). Coty Inc. image. Available from: https://www.nyse.com/events/3016426100/Coty-Inc-NYSE-COTY-Rings-TheNYSE-Opening-Bell [Accessed 8 March 2020]

Parida, V., Rönnberg-Sjödin, D., Wincet, J., \& Ylinenpää, H. (2013). Win-Win collaboration, functional product challenges and value-chain delivery: A case study approach. Procedia CIRP, 11, 86-91.

Randelli, F., \& Lombardi, M. (2014). The role of leading firms in the evolution of SME clusters: evidence from the leather products cluster in Florence. European Planning Studies, 22(6), 1199-1211.

Rowley, C., Quang, T., \& Warner, M. (2007). To what extent can management practices be transferred between countries? The case of human resource management in Vietnam. Journal of world business, 42(1), 113-127.

Sardinha, E. (2017). The New EU-Led Approach to Investor-State Arbitration: The Investment Tribunal System in the Comprehensive Economic Trade Agreement (CETA) and the EU-Vietnam Free Trade Agreement. ICSID Review-Foreign Investment Law Journal, 32(3), 625-672.

Schweiger, E., Grewal, D., Roggeveen, A. L., \& Beitelspacher, L. S. (2020). Managing the luxury shopping experience: implications for retail channels. In Research Handbook on Luxury Branding. Edward Elgar Publishing.

Shen, B., \& Mikschovsky, M. (2019). Introduction to fashion supply chain management in Asia. In Fashion Supply Chain Management in Asia: Concepts, Models, and Cases (pp. 1-17). Springer, Singapore.

Sikarskie, A. (2019). Fashionability: Abraham moon and the creation of British cloth for the global market, Fashion, Style, \& Popular Culture, 6(2), 303-306.

Silva, E. S., Hassani, H., Madsen, D. Ø., \& Gee, L. (2019). Googling fashion: forecasting fashion consumer behaviour using google trends. Social Sciences, 8(4), 111.

Silvano, M. D. C. L. F. (2020). Playing against the rules: how a digital strategy can enhance a luxury business: the case of Burberry, Available at https://repositorio.ucp.pt/handle/10400.14/29675 [Accessed 28 April 2020].

Syakur, A., Zainuddin, H. M., \& Hasan, M. A. (2020). Needs Analysis English For Specific Purposes (ESP) For Vocational Pharmacy Students. Budapest International Research and Critics in Linguistics and Education (BirLE) Journal, 3(2), 724-733.

USDA Foreign Agriculture Service (2018). Cotton and Products Annual. Available from: https://gain.fas.usda.gov/Recent\%20GAIN\%20Publications/Cotton\%20and\%20Prod ucts\%20Annual_Hanoi_Vietnam_4-132018.pdf?fbclid=IwAR36IYCHdXxSYGHa38U4NKS23LUz5OGt3us9W1tmkxZxC_qT1HaJzVQuxo [Accessed 11 March 2020]

Vaaland, T. (2004). Improving project collaboration: start with the conflicts. International Journal of Project Management, 22(6), 447-454.

Van Nguyen, L. T., Nayak, R., Watkins, J., \& Nguyen, P. N. D. (2019). Drivers of social media disengagement: a study of young consumers in Vietnam. Young Consumers. 246-263. 
Vietcetera (2019). Vietnamese Fashion Brands: The Future of Brick and Mortar Retail. Available from: http://vietcetera.com/vietnamese-fashion-brands-the-future-of-brickand-mortar-retail/ [Accessed 10 March 2020]

Vinerean, S., \& Opreana, A. (2019). Social Media Marketing Efforts of Luxury Brands on Instagram. Expert Journal of Marketing, 7(2), 144-152.

Voluntary National Review (2018). Vietnam: Sustainable Development Knowledge Platform.

Available

from: https://sustainabledevelopment.un.org/memberstates/vietnam [Accessed 9 March 2020].

Vuong, B. N., \& Khanh Giao, H. N. (2020). The impact of perceived brand globalness on consumers' purchase intention and the moderating role of consumer ethnocentrism: An evidence from vietnam. Journal of International Consumer Marketing, 32(1), 4768.

Vuong, T. T., Semerák, V., \& Vuong, Q. H. (2019). The Vietnamese economy at the crossroads. In Southeast Asia and the ASEAN Economic Community (pp. 91-143). Palgrave Macmillan, Cham.

Webster, J. and Watson, R.T. (2002). Analyzing the past to prepare for the future: writing a literature review, MIS Quarterly, 26( 2), xiii-xxiii.

Wood, M., Wood, M. and profile, V. (2014). Burberry builds on core competence of digital marketing.

Available

from: http://essentialmarketingplanning.blogspot.com/2014/06/burberry-builds-on-corecompetence-of.html [Accessed 8 April 2020] 